\title{
Leadership Competency Formation in Management Students Using Mobile Learning Technologies
}

\section{Formación de competencias de liderazgo en estudiantes de gestión que utilizan tecnologías de aprendizaje móvil}

\author{
Ekaterina Alexandrovna Pogrebinskaya \\ Sechenov University, Moscow, Russia \\ https://orcid.org/0000-0002-7487-9244 \\ Polina Vasilievna Fursova \\ Moscow Automobile and Road Construction State Technical University (MADI), Moscow, \\ Russia \\ https://orcid.org/0000-0002-9819-6499 \\ Elman Said-Mokhmadovich Akhyadov \\ Chechen State University, Grozny, Russia \\ https://orcid.org/0000-0002-0793-1727
}

Received 09-08-20 Revised 10-10-20

Accepted 20-12-21 On line 03-17-21

*Correspondencia

Email: pogrr@yandex.ru

(c) Universidad San Ignacio de Loyola, Vicerrectorado de Investigación, 2021. 


\section{Summary}

The focus of education on world standards predetermines the need to modernize the forms, methods, and means of teaching taking into account the current level of development of Internet technologies and information communications. Mobile learning reflects the educational trends most fully as it provides continuous access to information at any time. It should be noted that the development of mobile technologies makes portable mobile devices more usable and universal. With the development of mobile technologies, the need for quick access to information and the acquisition of knowledge has increased, as well as the mobility of the population. Therefore, the search for new approaches in organizing the educational process and creating educational materials accounting for the preferences of modern students and the information society as a whole becomes especially urgent. The goal of the study is to reveal the experience of implementing mobile learning based on the example of teaching the "Fundamentals of Leadership" course. Based on an experimental study, the study of the influence of the use of mobile learning technologies on the formation of leadership competency in management students is carried out.

Keywords: Mobile Devices, Distance Course, Electronic Manual, Fundamentals Of Leadership, Leadership Competency.

\section{Resumen}

El enfoque de la educación en los estándares mundiales predetermina la necesidad de modernizar las formas, métodos y medios de enseñanza teniendo en cuenta el nivel actual de desarrollo de las tecnologías de Internet y las comunicaciones de información. El aprendizaje móvil refleja las tendencias educativas de forma más completa, ya que proporciona acceso continuo a la información en cualquier momento. Cabe señalar que el desarrollo de tecnologías móviles hace que los dispositivos móviles portátiles sean más utilizables y universales. Con el desarrollo de las tecnologías móviles, ha aumentado la necesidad de acceso rápido a la información y la adquisición de conocimientos, así como la movilidad de la población. Por tanto, la búsqueda de nuevos enfoques en la organización del proceso educativo y la creación de materiales educativos que respondan a las preferencias de los estudiantes modernos y de la sociedad de la información en su conjunto se vuelve especialmente urgente. El objetivo del estudio es revelar la experiencia de implementar el aprendizaje móvil a partir del ejemplo de la enseñanza del curso "Fundamentos del Liderazgo". A partir de un estudio experimental, se lleva a cabo el estudio de la influencia del uso de tecnologías de aprendizaje móvil en la formación de competencias de liderazgo en estudiantes de gestión.

Palabras clave: Dispositivos móviles, Curso a distancia, Manual electrónico, Fundamentos del liderazgo, Competencia de liderazgo.

\section{Introduction}

In the realities of the information society, the leading world countries currently focus on providing the population with high-quality services using technologies that guarantee fast and effective communication (Gramma et al., 2020; Varenina et al., 2020). The provision of mobile communication services prompted the development of mobile learning (ML) for university 
students (Campbell, Kwak, 2011; Shtukareva et al., 2020). In modern times, university students are fully equipped with mobile devices (smartphones, tablets, netbooks, etc.) which allows using them in the educational process. The use of available software (browsers and cloud services) allows students to study anywhere at any time (Ciampa, 2014; Kukulska-Hulme, 2013; Akishina, Sevryukova, 2020).

ML can currently be considered a promising direction in the development of distance education and electronic educational process management. Such great attention to the implementation of mobile communication technologies owes to the fact that their spread significantly outpaces the development of Internet technologies (Medkova, 2020; Saktaganova et al., 2020).

\section{Literature review}

Researchers note (Jeng et al., 2010; Bukharaev, Altaher, 2017) that the realization of ML using various mobile devices presents an effective technology allowing school and university students to acquire knowledge, increase its volume, and develop skills and competencies in obtaining information for learning, as well as a certain form of professional training and a means of maintaining the productivity of the educational process with the student not being dependent on time, place, or location.

K. Peters (2007) believes that mobile devices portable computers provide unique educational opportunities, specifically: a) mobility; b) social interactivity; c) context-sensitivity (the ability to collect data unique for the present location, environment, and time, as well as artificial data); d) connection to various devices, as well as to networks, to collect information and data; e) individuality (individual educational trajectory on the way of acquiring knowledge).

Therefore, the use of mobile technologies in education presents a promising direction in the work of higher education institutions.

Researchers' viewpoints on the essence of ML are presented in Table 1.

Table (1): The essence of ML

\begin{tabular}{|l|l|}
\hline Author(s) (source) & The essence of ML \\
\hline $\begin{array}{l}\text { Crescente L.M, Lee } \\
\text { D. (2011) }\end{array}$ & $\begin{array}{l}\text { Presents one of the new directions in the development of distance } \\
\text { learning. However, the means of mobile educational information and } \\
\text { communication technologies can be used not only in mobile and } \\
\text { distance learning. Thus, distance and ML support systems can be used } \\
\text { as ML software to support classroom learning as in their nature they } \\
\text { present teaching software focused on centralized storage and distributed } \\
\text { presentation of teaching methods. }\end{array}$ \\
\hline $\begin{array}{l}\text { Luna-Nevarez C., } \\
\text { McGovern E. (2018) }\end{array}$ & $\begin{array}{l}\text { An innovative educational approach based on which universities create a } \\
\text { new learning environment in which students can access learning } \\
\text { materials at any time and from any place which makes the educational } \\
\text { process attractive, democratic, and comfortable and encourages } \\
\text { students' self-education and lifelong learning. }\end{array}$ \\
\hline $\begin{array}{l}\text { El-Hussein M.O.M., } \\
\text { Cronje J.C. (2010) }\end{array}$ & $\begin{array}{l}\text { Creative teaching strategy focused on the ability of modern } \\
\text { smartphones, tablets, and laptops to become fully functional helping } \\
\text { tools for students when needed. }\end{array}$ \\
\hline $\begin{array}{l}\text { Vázquez-Cano E. } \\
\text { (2014) }\end{array}$ & $\begin{array}{l}\text { A type of distance learning and an opportunity to receive or present } \\
\text { educational content on personal mobile devices (smartphones, tablets, e- } \\
\text { readers, etc.). Educational content involves digital learning resources } \\
\text { including any form of content or media accessible from a personal } \\
\text { mobile device. }\end{array}$ \\
\hline
\end{tabular}


The study hypothesis states that the introduction of ML in the educational environment of a university will contribute to the formation of students' systems of knowledge including modern leadership theories, psychological characteristics of leadership, theoretical foundations of effective leadership, team management technologies, management styles, methods for the development and improvement of one's management style, and practical methods of effective management under the conditions of risk and uncertainty.

Proving the proposed hypothesis requires solving a range of tasks:

- selecting study participants;

- developing the "Fundamentals of Leadership" distance course and the "Basics of Leadership" electronic manual;

- determining the criteria for the evaluation of students' knowledge;

- conducting quantitative processing, analysis, and interpretation of the obtained data;

- formulating conclusions and prospects for further research based on the acquired results.

The present article consists of an introduction, literature review, study methods, results, their discussion, and conclusion.

\section{Materials and methods}

The goal and objectives of the study determine the use of several methods including theoretical: analysis, generalization, and systematization of studies on the use of ML technologies, and empirical methods: the experimental testing of the effectiveness of ML in students.

The experimental testing of the effectiveness of ML in students in studying the "Fundamentals of Leadership" course was conducted in the 2019-2020 academic year. The experiment involved 303 students. The control group (CG) included 151 students and the experimental group (EG) included 152 students.

The assessment of students' knowledge was carried out following the criteria presented in the course program. Students have to possess knowledge of:

- the dependence of leadership style on specific people and situations;

- major differences between leadership and management;

- how traditional leaders use traditional leadership methods;

- the differences between leadership styles;

- the characteristics of the main types of leadership;

- how to motivate people;

- how to delegate authority;

- how to distinguish between a dialogue and a discussion; 
- how to use communication tools to influence others;

- how to create a monolithic team;

- how to help one's followers reach their maximum potential;

- the core values associated with the achievement-oriented culture.

\section{Results}

The results of diagnostics of the students' level of training in the "Fundamentals of Leadership" course before and after the introduction of ML using the distance course and the "Basics of Leadership" online manual are presented in Table 2.

Table (2): Results of diagnostics of students' progress in the "Fundamentals of Leadership" discipline (before and after the experiment)

\begin{tabular}{|c|c|c|c|c|c|c|c|c|}
\hline \multirow{2}{*}{$\begin{array}{l}\text { Knowledge } \\
\text { level }\end{array}$} & \multicolumn{4}{|c|}{ Pre-experiment } & \multicolumn{4}{|c|}{ Post-experiment } \\
\hline & \multicolumn{2}{|c|}{ CG } & \multicolumn{2}{|c|}{ EG } & \multicolumn{2}{|c|}{ CG } & \multicolumn{2}{|c|}{ EG } \\
\hline low & 32 & $21.2 \%$ & 39 & $25.7 \%$ & 29 & $19.2 \%$ & 6 & $3.9 \%$ \\
\hline average & 87 & $57.6 \%$ & 83 & $54.6 \%$ & 88 & $58.3 \%$ & 92 & $60.6 \%$ \\
\hline high & 32 & $21.2 \%$ & 30 & $19.7 \%$ & 34 & $22.5 \%$ & 54 & $35.5 \%$ \\
\hline
\end{tabular}

The dynamics of changes in the level of students' knowledge in the "Fundamentals of Leadership" discipline after the introduction of ML are presented in Table 3.

Table (3): Dynamics of changes in the level of students' knowledge after ML

\begin{tabular}{|l|l|l|l|l|}
\hline \multirow{2}{*}{ Knowledge level } & \multicolumn{4}{|l|}{ Number of students } \\
\cline { 2 - 5 } & CG & EG & $-21.71 \%$ \\
\hline low & -3 & $-1.99 \%$ & -33 & $+5.92 \%$ \\
\hline average & +1 & $+0.66 \%$ & +9 & $+15.79 \%$ \\
\hline high & +2 & $+1.32 \%$ & +24 & \\
\hline
\end{tabular}

As demonstrated in Table 3, the number of students with a high level of development of knowledge increased by $1.32 \%$ in the CG and by $15.79 \%$ in the EG; the number of students at the average level grew by $0.66 \%$ in the CG and by $5.92 \%$ in the EG; the number of students with the low level of knowledge decreased by $1.99 \%$ in the CG and by $21,71 \%$ in the EG.

The reliability of the experiment results was tested using Pearson's $\chi^{2}$ test. To verify the discovered differences in the level of knowledge between the CG and EG, we formulated the zero and alternative hypotheses. $\mathrm{H} 0$ suggests that the level of knowledge in the "Fundamentals of Leadership" course does not differ significantly in the CG and the EG. H1 states that the level of knowledge in the CG and the EG is fundamentally different.

Pearson's $\chi^{2}$ test was calculated using the data presented in Table 2 and a Microsoft Excel spreadsheet.

Comparing the obtained values of Pearson's $\chi^{2}$ test $\left(\chi^{2} \mathrm{emp}\right)$ with the critical value of the criterion $(\chi 2$ crit) considering the data of statistical processing before and after the experiment, we can make the following conclusions:

pre-experiment results: $4.11<7.81$, therefore, the EG and the CG belong to the same general population; $\mathrm{H} 0$ hypothesis is accepted, that is, there is no significant difference in the knowledge of the "Fundamentals of Leadership" course in the EG and the CG; 
post-experiment: $80.25>7.81$, therefore, we can reject the zero hypothesis and accept the alternative one: the significant difference between the $\mathrm{CG}$ and the EG presents a consequence of introducing ML for students studying the "Fundamentals of Leadership".

The aforementioned allows us to state that the introduction of ML in the educational environment of the university significantly contributed to the formation of students' systems of knowledge including modern leadership theories, psychological characteristics of leadership, theoretical foundations of effective leadership, team management technologies, management styles, methods for the development and improvement of one's management style, and practical methods of effective management under the conditions of risk and uncertainty.

\section{Discussion}

Let us consider the organization of ML for management students in the course of which the aforementioned results were obtained in greater detail.

The organization of ML in universities requires the following conditions to be met (the required minimum):

1. students and teachers have to have access to mobile devices;

2. the developed electronic educational courses (electronic textbooks and teaching aids, educational sites, distance learning courses) have to be accessible;

3. feedback between a teacher and a student has to be organized.

The analysis of the possibilities of introducing ML showed that students and teachers are fully equipped with mobile devices (condition 1 is met).

The second requirement was met through the development of the "Fundamentals of Leadership" distance course and the "Basics of Leadership" electronic manual for mobile devices.

A wide range of software instruments currently exists for the development of distance courses allowing for distance learning and the creation of an educational environment of an Open University (Blackboard Learn, WebCT, eFront, SharePoint LMS) (Pearce, Rice, 2013).

The common characteristic of these programs resides in that they allow tracking students' learning progress, storing their characteristics, calculating the number of activities in specific sections of the website, as well as determining the time it took a student to complete a certain section of the course. The systems allow users to register for the course. All information about the ongoing events and the necessary reports are automatically sent to registered users. Students can be arranged into groups. Moreover, these programs present opportunities for testing students' knowledge and organizing online communication. Nevertheless, the main disadvantages of such software include the cost of the system and the cost of its implementation, development, and maintenance of courses (Liu et al., 2010).

Analyzing various platforms for organizing a continuous learning system for primary school teachers, we discovered that several universities use the Moodle platform. As a result of the analysis and comparison of the above-mentioned platforms based on the pedagogical, didactic, organizational, technological, and financial characteristics of distance education, we concluded that the system of distance education for students can be organized using the Moodle platform. 
Thus, we chose the Moodle distance learning platform to create the "Fundamentals of Leadership" distance course. Moodle presents a free open-source learning management system. It realizes the philosophy of "social constructivism pedagogics" and focuses on the organization of interaction between a teacher and students although it is also suitable for organizing traditional distance courses and supporting classroom learning. This system allows creating electronic educational courses and carrying out both distance and in-classroom learning. This software product is developed following the standards of educational information systems and meets the characteristics of interoperability, reusability, adaptability, durability, availability, and cost-effectiveness. Teachers can use Moodle in a variety of ways to create distance courses, upload files, create lessons, forums, and chats, hold tests and exams, quickly and easily change the educational materials, set time limitations for specific tasks, etc. (Oproiu, 2015).

The content of the "Fundamentals of Leadership" is directly aimed at the formation of leadership competency in students in the course of studying the course.

We should highlight that a distance course created in Moodle realizes the principle of hypertext content of education (the opportunity to access educational materials through hyperlinks) (Wood, 2010). These hyperlinks can be found in the text of educational materials throughout the entire course.

The open space of a distance course undoubtedly suggests certain roles to be taken on by its users. The administrator makes any type of alterations to the distance learning environment and is responsible for the correct functioning of the distance course, its settings, and the correctness of the data on the site, as well as the registration of users; tutors are represented by teachers, managers, entrepreneurs, businessmen, and heads of local government bodies who can be involved in teaching the "Fundamentals of Leadership" course and have the right to access the distance course; students are those who study the "Fundamentals of Leadership" course.

Thus, the "Fundamentals of Leadership" distance course presents a powerful didactic resource for the formation of students' leadership competencies in the university environment which includes the means of studying the theoretical foundations of the discipline (the information component), the means of supporting practical classes, coursework, projects, individual assignments (the practice-oriented component), knowledge assessment tools (the evaluation component), the means of interaction between a teacher and a student (the interactive component), methodological instructions for studying the course (the methodological component), and the course management tools (the management component).

The "Basics of Leadership" electronic manual for mobile devices was created using Dr. Explain software for creating help files, manuals, online user manuals, guides, and technical documentation for software and technical systems. Studies demonstrate (Moreno et al., 2017) that Dr. Explain can be conveniently used to create CHM reference files, printed documents, and e-books which allows using it to create hypertext electronic educational resources. Electronic educational resources created in this program can be saved in two formats (PDF and HTML) which completely resolves the problem using it on various types of modern computer equipment: computers, laptops, netbooks, Apple tablet computers, smartphones, iPhones, etc.

Overall, researchers believe (Keengwe, Georgina, 2012) that the opportunities presented by Dr. Explain software make it highly convenient and effective for the development of various electronic educational resources ranging from electronic lectures and manuals to entire e-course packages of disciplines and online educational resources.

The "Basics of Leadership" electronic manual presents a hypertext environment for a PDF file. The navigation panel, hyperlinks, and automated content are used to navigate it and scrollbars are used to browse through pages. 
It should be noted that creating electronic teaching guides in formats supported by mobile devices is essential for ML. Hypertext study materials in PDF format are currently highly popular and quite affordable. We recommend using programs like Adobe Acrobat, Adobe Reader, PDFMaster, and others to view these electronic manuals (in PDF format). These programs are easy to install on any computer, laptop, tablet, or smartphone which allows studying from anywhere at any time and using any device (Cheong et al., 2012).

It is advisable to organize feedback between a student and a teacher using modern Internet technologies: e-mail, Google services (chats, video conferencing), social networks, Viber, Skype, Telegram, WhatsApp, etc. These services and their capacities in terms of interaction solve the problem of organizing quick feedback for the teacher (correspondence, file sharing, video calls, virtual consultations, etc.) (Foti, Mendez, 2014).

Therefore, organizing ML at a university requires a teacher to:

- have (develop) electronic educational resources in the PDF format (from lectures, practical and individual assignments to entire electronic textbooks, study guides, and teaching materials for the discipline);

- provide students with access to these materials: post them on their website, social media, or university website;

- communicate with students in the process of ML (correspondence, file exchange, Q\&A's, testing and assessment, etc.).

To ensure effective ML, a student has to:

- download electronic learning materials to their mobile device;

- communicate with the teacher in the process of ML (correspondence, SMS, file exchange, Q\&A's, etc.);

- have the desire to learn.

To ensure the effective functioning of the mobile educational process at a university, sets of electronic educational materials (PDF files) have to be developed. The set of educational materials for ML should include: teaching materials;

- methodical guidelines (instructions) on the overall organization of ML and the use of

- lecture notes on the discipline;

- practical tasks (laboratory practice);

- individual tasks;

- audio and video lectures (recommended).

In general, ML as a form of resource-oriented learning allows transforming the educational process using modern information and communication technologies with an emphasis on Internet technologies (Table 4).

Table (4): Transformation of the educational process in the context of ML at a university 


\begin{tabular}{|c|c|}
\hline Educational format & The technology used \\
\hline Lecture: & $\begin{array}{l}\text { video conference (combined with a slide show); } \\
\text { e-learning resources (textbooks, study guides, distance courses); } \\
\text { audio lectures; } \\
\text { video lectures (convenient to post on YouTube video hosting, } \\
\text { cloud services, or social media). }\end{array}$ \\
\hline \multicolumn{2}{|r|}{ (1) } \\
\hline individual & $\begin{array}{l}\text { SMS (reminders about completed and submitted tasks and papers); } \\
\text { Emails; } \\
\text { messages or video calls in social media applications, Viber, Skype, } \\
\text { Telegram, WhatsApp. }\end{array}$ \\
\hline group & $\begin{array}{l}\text { mailing list; } \\
\text { forum (chat); } \\
\text { groups created on social networking sites (instruments of } \\
\text { discussions, topics, posting on the webpage, exchanging links, } \\
\text { etc.); } \\
\text { a teacher's website (guestbook, feedback form). }\end{array}$ \\
\hline \multicolumn{2}{|r|}{ 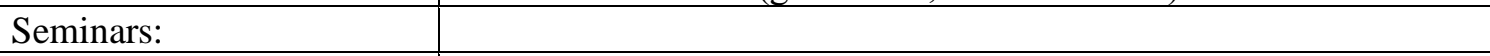 } \\
\hline regular & conference (all types). \\
\hline round table & $\begin{array}{l}\text { conference (all types); } \\
\text { forums (chats). }\end{array}$ \\
\hline brainstorming & $\begin{array}{l}\text { conference (audio or video); } \\
\text { forums (chats). }\end{array}$ \\
\hline \multicolumn{2}{|l|}{ Practical lessons: } \\
\hline $\begin{array}{ll}\text { completing } & \text { practical } \\
\text { assignments } & \end{array}$ & $\begin{array}{l}\text { Email; } \\
\text { mailing list; } \\
\text { messages on social media, Viber, Skype, Telegram, WhatsApp; } \\
\text { distance course environment. }\end{array}$ \\
\hline $\begin{array}{l}\text { completing other types of } \\
\text { assignments }\end{array}$ & $\begin{array}{l}\text { conference (video or audio); } \\
\text { a student's electronic portfolio; } \\
\text { website of a student or a group of students. }\end{array}$ \\
\hline \multicolumn{2}{|l|}{ Knowledge assessment: } \\
\hline $\begin{array}{l}\text { progress report or student } \\
\text { portfolio }\end{array}$ & $\begin{array}{l}\text { Email; } \\
\text { mailing list; } \\
\text { testing systems; } \\
\text { website of a student or a group of students; } \\
\text { distance course environment. }\end{array}$ \\
\hline exams & $\begin{array}{l}\text { testing systems; } \\
\text { video conferencing; } \\
\text { distance course environment. }\end{array}$ \\
\hline $\begin{array}{l}\text { presentation of individual } \\
\text { educational projects }\end{array}$ & $\begin{array}{l}\text { conference (video or audio); } \\
\text { website of a student or a group of students; } \\
\text { discussions on social media, in Viber, Skype, Telegram, the guest } \\
\text { page of a teacher's website. }\end{array}$ \\
\hline
\end{tabular}

\section{Conclusion}

The conducted study leads us to the following conclusions. ML contributes to the formation of flexible learning due to the new opportunities of mobile telecommunication services for sending texts and graphics and video conferencing. Modern didactics is changing in terms of the content of the fundamental principles of learning in the context of a mobile form of resource-based learning and requires the development of electronic educational resources for mobile devices. In the context of ML, the principle of guided interactive self-learning becomes the primary determining factor. ICT and Internet technologies are changing the methods of 
teaching transforming traditional methods through the means of specific services based on various formats of information presentation, as well as provide a high degree of interactivity between a teacher and a student, ensure effective feedback through mobile devices, and increase the share of collaborative learning and group learning in the classroom.

The study results confirm the hypothesis that the introduction of ML in the educational environment of a university will contribute to the formation of students' systems of knowledge including modern leadership theories, psychological characteristics of leadership, theoretical foundations of effective leadership, team management technologies, management styles, methods for the development and improvement of one's management style, and practical methods of effective management under the conditions of risk and uncertainty.

Prospects for further research include: the coordination and methodical support of ML; the development of a comprehensive approach to creating an educational and scientific information environment that would include a telecommunication infrastructure, information resources for education and science, networks of electronic libraries, and interuniversity virtual laboratories; joining international educational and research networks and information resources; the formation and improvement of pedagogical support of ML.

\section{Acknowledgments}

The authors would like to acknowledge the management of the RUDN University. The publication was prepared with the support of the "RUDN University Program 5-100".

\section{References}

Akishina, E., Sevryukova, N. (2020). Decorative Effect in the Solution of Children's Drawings on Historical Topics. Utopía y Praxis Latinoamericana, 25(Extra 5): 22-30.

Bukharaev, N., Altaher, A.W. (2017). Mobile Learning Education has Become More Accessible. American Journal of Computer Science and Information Technology, 5(2). https://doi.org/10.21767/2349-3917.100005

Campbell, S.W., Kwak, N. (2011). Mobile Communication and Civil Society: Linking Patterns and Places of Use to Engagement with Others in Public. Human Communication Research, 37: 207-222.

Cheong, C., Bruno, V., Cheong, F. (2012). Designing a mobile-app-based collaborative learning system. Journal of Information Technology Education: Innovations in Practice, 11(1): 94-119.

Ciampa, K. (2014). Learning in a mobile age: an investigation of student motivation. Journal of Computer Assisted Learning, 30(1): 82-96.

Crescente, L.M, Lee, D. (2011). Critical issues of m-learning: design models, adoption processes, and future trends. Journal of the Chinese Institute of Engineers, 28: 111123.

El-Hussein, M.O.M., Cronje, J.C. (2010). Defining mobile learning in the higher education landscape. Educational Technology \& Society, 13(3): 12-21.

Foti, M.K., Mendez, J. (2014). Mobile Learning: How Students Use Mobile Devices to Support Learning. Journal of Literacy and Technology, 15(3): 58-78.

Gramma, D.V., Filistova, N.Y., Avdeeva, T.I., Iakovets, T.I., Lobazova, O.F. (2020). Distance learning of students of humanitarian faculties: mobile learning applications. Eurasian Journal of BioSciences, 14: 6181-6187.

Jeng, Y.L., Wu, T.T., Huang, Y.M., Tan, Q., Yang, S.J.H. (2010). The added-on impact of mobile application on learning strategies: a review study. Educational technology \& Society, 13(3): 3-11.

Keengwe, J., Georgina, D. (2012). The digital course training workshop for online learning and teaching. Education and Information Technologies, 17(4): 365-379. 
Kukulska-Hulme, A. (2013). Perspectives: limelight on mobile learning: integrating education and innovation. Harvard International Review, 34(4): 12-16.

Liu, Y., Li, H., Carlsson, C. (2010). Factors driving the adoption of M-learning: An empirical study. Computers \& Education, 55(3): 1211-1219.

Luna-Nevarez, C., Mcgovern, E. (2018). On the Use of Mobile Apps in Education. The Impact of Digital Magazines on Student Learning, 47(1): 17-31.

Medkova, E. (2020). Analysis of Semantic Approaches and Perspective of Cultural Codes in Teaching Education in General. Utopía y Praxis Latinoamericana, 25(Extra 5): 163178.

Moreno, V., Cavazotte, F., Alves, I. (2017). Explaining university students' effective use of e-learning platforms. British Journal of Educational Technology, 48(4), 995-1009.

OPROIU, G.C. (2015). A Study about Using E-learning Platform (Moodle) in Univeristy Teaching Process. Procedia-Social and Behavioral Sciences, 180: 426-432.

Pearce, K.E., Rice, R.E. (2013). Digital Divides From Access to Activities: Comparing Mobile and Personal Computer Internet Users. Journal of Communication, 63(4): 721-744.

Peters, K. (2007). M-Learning: Positioning educators for a mobile, connected future. The International Review of Research in Open and Distributed Learning, 8(2): 113-132.

Saktaganova, Z., Sagatova, A., Nurligenova, Z. (2020). Historiographical Review of theProblem "Woman of the USSR in the Great Patriotic War -Hero or Victim?" Utopía y Praxis Latinoamericana, 25(Extra 5): 279-289.

Shtukareva, E.B., Sergeeva, S., Zolotukhina, Yu., Orlyuk, A., Kopylov, I.A. (2020). Internet Communications in the Context of Restrictions on Population Mobility. International Journal of Advanced Trends in Computer Science and Engineering, 9(3): 3904-3909.

Varenina, L.P., Goncharov, V.V., Tonoyan, Kh.A., Bazhin, G.M., Ismailova, Kh.E. (2020). Organization of teacher-student pedagogical interaction in blended learning through mobile messengers. Revista Inclusiones, 7(Especial), 357-368.

Vázquez-Cano, E. (2014). Mobile distance learning with smartphones and apps in higher education. Educational Sciences: Theory and Practice, 14(4), 1505-1520.

Wood, S. (2010). Technology for Teaching and Learning: Moodle as a Tool for Higher Education. International Journal of Teaching and Learning in Higher Education, 22(3): 299-307. 